The Impact of the 2008 Global Crisis On Small Economies in the Caribbean

Harvey W. Armstrong \& Robert Read*

Department of Geography, University of Sheffield UK

ORCID 000-002 -2534-848X (h.armstrong@sheffield.ac.uk)

Lancaster University Management School, Lancaster, UK,

ORCID 0000-0002-8001-1900 (r.read@lancaster.ac.uk)

*corresponding author 


\title{
The Impact of the 2008 Global Crisis On Small Economies in the Caribbean
}

\begin{abstract}
This paper investigates the impact of the global 2008 crisis on the Caribbean region, with particular focus on its many small tourism-dependent economies. Specialization in tourism and, in some cases, offshore financial services has been a successful specialization strategy for many small economies but has made them highly susceptible to exogenous economic shocks. The paper utilizes cluster analysis to identify five distinct pre-crisis patterns of sectoral specialization in Caribbean economies generally. The 2008 crisis is shown to have had very distinct cluster-specific effects, with small economies specializing in tourism and financial services being the worst affected. These findings raise important questions regarding the future sustainability of this sectoral growth template previously adopted by many successful small economies.

Cette étude examine l'impact de la crise mondiale de 2008 sur la région des Caraïbes, avec un accent particulier sur ses nombreuses petites économies dépendantes du tourisme. $\mathrm{La}$ spécialisation du tourisme et, dans certains cas, des services financiers offshore a été une stratégie de spécialisation réussie pour de nombreuses petites économies, mais les a rendus très vulnérables aux chocs économiques exogènes. L'étude utilise l'analyse par grappes pour identifier cinq modèles distincts de spécialisation sectorielle d'avant la crise dans les économies des Caraïbes en général. Il a été démontré que la crise de 2008 a eu des effets très spécifiques sur les clusters, les petites économies spécialisées dans le tourisme et les services financiers étant les plus touchées. Ces résultats soulèvent d'importantes questions concernant la viabilité future de ce modèle de croissance sectorielle adopté précédemment par de nombreuses petites économies prospères.
\end{abstract}

Key words: Small economies; Caribbean; global crisis; sectoral specialization; cluster analysis; tourism-dependence; global crisis; economic performance; crisis impact. Petites économies; les Caraïbes; la crise mondiale; l'impact de la crise; croissance économique; spécialisation sectorielle; l'analyse par grappes; dépendance touristique.

9,691 words, excluding Abstract. 


\section{The Impact of the 2008 Global Crisis On Small Economies in the Caribbean}

\section{Introduction}

The foundation of the growth success of many small economies in recent decades has been deepening integration with the global economy based upon a high degree of openness to international trade and supported by the expansion of key sectors in which they have a comparative advantage, notably tourism and 'offshore' financial services (see Armstrong et al. 1998). The Caribbean region, in particular, is characterized by an unusually large number of small economies, many of which have based their growth strategies upon the development of these two key sectors.

This paper investigates the comparative economic performance of small economies in the Caribbean region in the periods immediately prior to and since the global economic crisis in 2008. It has two principal objectives: to ascertain whether the Caribbean states fell into clear groups or 'clusters' in terms of their sectoral structures in 2007 , immediately prior to the crisis; and the extent to which their performance in the aftermath of the crisis has been influenced by their pre-existing cluster membership. The analysis incorporates both sovereign states and non-sovereign associated territories in the Caribbean.

The paper provides a summary of the literature on the determinants of economic growth performance and sectoral structure in small economies, with specific reference to the Caribbean region. The analytical methodology is described briefly. The principal findings are presented in two parts. The first part develops a classification of Caribbean entities using statistical cluster analysis for 2007. The second looks at evidence of systematic variation in economic performance between them during and after the financial crisis. The concluding section reviews the key findings and explores their policy implications.

\section{Trade, Sectoral Specialization \& Growth Volatility in Small Economies}

Small economies, including many islands and/or archipelagos, face a range of critical longterm growth challenges because of their size (outlined in an extensive literature, e.g.: Robinson, 1960; World Development, 1980, 1993; Jalan, 1982; Dommen and Hein, 1985; Armstrong and Read, 1998; Briguglio, 1995). These principal challenges are: their small populations; limited resources; diseconomies of small scale; the need for output specialization; export concentration; size-induced structural openness to international trade; 
high exposure to global economic conditions; and consequent susceptibility to high growth volatility. In spite of these challenges, many small economies have achieved sustained economic growth, high per capita incomes and feature in the World Bank's Upper-Middle and High Income categories (World Development Indicators). Unsurprisingly therefore, empirical analyses find little evidence of any systematic adverse effects of small size on growth (e.g., Blazic-Metner and Hughes, 1982; Armstrong et al., 1998; Armstrong and Read, 2000, 2006; Easterly and Kraay, 2000; Alesina et al., 2005; Rose, 2006). Many small economies appear to have devised and implemented effective countervailing growthpromoting strategies owing to the quality of their governance.

\section{Openness to Trade \& Growth in Small Economies}

International trade is a critical contributor to growth in small economies. Exports increase the extent of their markets and overcome some of the constraints imposed by diseconomies of small scale. Imports resolve the significant asymmetries between patterns of domestic production and consumption (Kuznets, 1960; Marcy, 1960). Small economies therefore necessarily pursue highly open trade regimes (i.e., 'structural openness' - Demas, 1965), reflected in trade to GDP ratios often greatly exceeding 100 per cent, that generate large trade multiplier effects (Ashoff, 1989). Structural openness however, heightens their exposure to commodity- as well as market-specific trade shocks. This exposure is often compounded by their exposure to environmental factors (e.g., hurricanes in the Caribbean). The long-run growth paths of small economies are therefore likely to be subject to significant volatility (Holmes, 1986; Briguglio, 1995; Armstrong and Read, 1998; Easterly and Kraay, 2000; Easterly, et al., 2001).

\section{Patterns of Sectoral Specialization \& Growth in Small Economies}

Structural openness to trade in small economies requires the patterns of domestic economic activity to be highly export-oriented, based upon their underlying comparative advantage (subject to trade costs). These activities are likely to be relatively scale neutral and less reliant upon low-cost labour, implying that labor-intensive industrialization is inappropriate (Lewis, 1955; Demas, 1965; Thomas, 1982). The pattern of sectoral specialization in more successful small economies is therefore more likely to embody greater human capital (Bhaduri et al., 1982). Empirical studies confirm the critical contribution of labor- and skill-intensive services - notably tourism and financial services - along with natural resources in high 
income small economies (Armstrong et al., 1998; Armstrong and Read, 2000; Read et al., 2012). This paper uses cluster analysis to identify distinct groups of Caribbean entities according to their structural characteristics and investigates the impact of the global economic crisis on these different clusters.

\section{Growth Volatility in Small Economies}

Growth volatility is primarily determined by the nature and extent of engagement with the global economy, growth strategies and susceptibility to natural catastrophe. Large-scale crosscountry studies generally find a significant negative empirical relationship between volatility and GDP growth (e.g., Ramey and Ramey, 1995; Rodrik, 1999; Hnatkovska and Loayza, 2003). The stabilizing effects of greater international trade and financial integration however, are argued to more than compensate for the destabilizing effects of terms of trade shocks (Cavallo, 2007). The greater susceptibility of developing economies generally to growth volatility is the critical outcome of interactions between domestic policy choices (poor governance) and sectoral specialization (see Loayza et al., 2007; Raddatz, 2007).

Nevertheless, there is little evidence of variation in volatility resulting from differences in levels of development, openness, sectoral specialization and size (Koren, 2007).

The structural characteristics of small economies expose them to several sources of growth volatility: export product and market concentration; export price and earnings volatility; dependence upon strategic imports (e.g., oil); and, in some cases, remoteness. Sectoral specialization therefore amplifies their exposure to exogenous economic shocks such that growth volatility is likely to be more pronounced than in larger economies, resulting in lower long-run trend rates of growth. The standard policy remedies against exposure to such shocks however, are highly constrained by their structural characteristics.

The empirical evidence indicates that small economies experience substantial growth volatility but the ameliorating effects of greater regional and global integration have generally outweighed these adverse growth effects (Easterly and Kraay, 2000; Easterly et al., 2001; Armstrong and Read, 2002; Alesina et al., 2005). The impact of the 2008 global financial crisis and its aftermath however, has been a 'double whammy' for the growth of small economies, including those in the Caribbean, because of their greater openness to trade and specialization in offshore financial services and tourism. 


\section{Research Methodology}

This paper explores whether the sectoral structure of economic activity in Caribbean sovereign states and associated territories influenced their growth performance immediately prior to the 2007 financial crisis and in its aftermath.

The paper examines the economic performance of 36 states and associated territories in the Caribbean based upon a deliberately wide definition of what constitutes the 'Caribbean region'. All entities with a Caribbean shoreline have been included and is therefore broader than the definitions used by CARICOM and CEPAL, among others. Much of the research attention on the Caribbean focuses exclusively on the islands in the region rather than including the larger states that border the Caribbean. The wider definition used in this paper has been chosen for three reasons:

- The performance of smaller Caribbean islands is of specific interest but that of larger islands and adjacent mainland states in the region is also of inherent interest.

- It is extremely useful to set the performance of the smaller Caribbean islands within the broader context of the region.

- A particular focus of the paper is on the role of sectoral specialization in influencing the impact of the global financial crisis, such that it is appropriate to incorporate states with larger natural resource bases and agricultural and manufacturing export sectors than is typical in the smaller Caribbean islands.

The research methodology is based upon cluster analysis (Everitt, 1993), a classificatory methodology that does not seek to develop causal analysis. Instead, a grouping algorithm is used to derive clusters of 'most similar' cases across an array of grouping variables. The 'cases' in this study are the 28 Caribbean states and associated territories for which suitable data are available. The 'cluster variables' are six sectoral structure variables together with one economic performance measure (Gross National Income - GNI - per capita).

The paper uses the Ward's Method, the default cluster analysis in the main software packages, including Minitab (employed here). The Ward's Method is an hierarchical agglomerative method, which begins with the number of clusters set equal to the number of cases (i.e., $\mathrm{n}=28$ here) and ending when all of the cases are left in a single cluster (containing all 28 cases). The results of this agglomerative algorithm are shown in a dendrogram (see Figure 1) which illustrates the precise way in which cases are clustered successively into 
larger groups. The Ward's Method uses squared Euclidean distance in its dissimilarity measure, defined as:

$\sum_{\mathrm{k}=1 \ldots \mathrm{n}}\left(\mathrm{x}_{\mathrm{ik}}-\mathrm{x}_{\mathrm{jk}}\right)^{2}$

where: $k=1 \ldots n$ are the grouping variables and $i=1 \ldots j \ldots m$ are the cases.

Two further important informed choices need to be made in cluster analysis, over and above the decisions concerning how many entities (i.e., 'cases') to include and what variables to use (i.e., 'cluster variables'):

- How many clusters to analyze. Having too many clusters is self-defeating since this tends towards treating each entity individually while too few clusters (e.g., one or two) obscures the very statistical variation of most interest. The standard approach, utilized here, seeks to identify the clearest possible clusters by examining the gap in similarity coefficient necessary for two clusters to eventually be merged by the cluster algorithm (i.e., the vertical axis on Figure 1). A 5-cluster solution is chosen here as the appropriate compromise between the desire to examine greater diversity and the need for a practicable number of distinct clusters.

- $\quad$ How to name the clusters. The method has no requirement to do so although naming facilitates ease of identification and inter-cluster analysis. This paper follows convention by naming the clusters using broad-brush summary labels although these may not always apply to every single case within the cluster (e.g., 'marginal' members such as Mexico and Puerto Rico in Cluster 3 in Figure 1).

Cluster analysis is used here to establish whether Caribbean states fall into clear clusters in terms of their sectoral structures and GNI per capita in 2007; i.e., the year preceding the financial crisis. The paper then proceeds to analyze an array of economic data on the subsequent economic performance of each Caribbean cluster in turn.

\section{A Classification of Caribbean States \& Associated Territories, 2007}

The Caribbean region is characterized by a large number of small economies, including sovereign states and non-sovereign territories, many of which are also islands. Further, the region contains the best-performing small economies globally in terms of high GNI per capita incomes after Western Europe (World Development Indicators). The growth of many small states in the region has been based on the development of financial services and tourism; 
sectors that were particularly badly affected by the global economic crisis (Kouame and Reyes, 2011; IMF, 2013). This paper investigates the impact of the global crisis in the context of its differential effects on distinct pre-crisis sectoral clusters in the region.

\section{Initial Sectoral Cluster Analysis for the Caribbean Region, 2007}

This section presents the results of a cluster analysis of the sectoral structures of Caribbean states and territories, focusing initially on: (a) those entities for which good quality comparable data exist; and (b) a very short list of variables where the best (i.e., most comprehensive coverage) data exist. The 28 states and territories included in this first cluster analysis, together with eight entities excluded because of inadequate or missing data, are listed in Table 1. All eight of the excluded entities (some 22 per cent) are associated territories rather than sovereign states.

[Table 1 here]

It can be seen from Table 1 that seven of the eight excluded entities are islands and, moreover, all are very small; the largest being Guadeloupe (population 447,200 in 2007). This demonstrates the extent of a serious truncation problem with large international data sets, even when a very restricted set of accessible variables is selected.

The seven cluster variables used in the analysis are set out in Table 2 . Their number is deliberately limited so as to maximize the coverage of states and territories. The variables are initially confined to a single economic performance variable (GNI per capita), together with six sectoral structure variables drawn from the research literature on small economies (agriculture, manufacturing, overnight tourist numbers, cruise tourist numbers, the presence of an offshore finance center and the existence of major natural resource exports).

[Table 2 here]

The results of the cluster analysis are presented in summary form as a dendrogram (Figure 1). The bottom of the graph lists the 28 cases (countries) clustered. The sequence by which the cases have been clustered can be seen by reading upwards until the final two 'super-clusters' come together at the top to produce a single cluster containing all 28 cases. There is also no single 'best' solution in terms of the appropriate number of clusters to isolate and examine but the very distinct five-cluster solution is chosen for analysis.

[Figure 1 here]

The average values of the variables for each member of the seven clusters are set out in Table 3. Comparing these in turn with the overall average for all 28 states provides a very simple 
but highly effective method of identifying the particular characteristics of each cluster. Cluster averages greater than the overall 28-state average (the 'All' column), are shown in bold.

[Table 3 here]

The values for Cluster 1 indicate economies that attract disproportionate numbers of both overnight and cruise tourists (per thousand population). Other sectors are either non-existent (offshore finance and natural resources) or else severely under-represented (agriculture and industry). The entities within this cluster are all small island states (Antigua \& Barbuda, Grenada, St Lucia and St Vincent \& The Grenadines) and appear to be classic examples of small island tourism economies - SITEs (McElroy, 2003, 2006; McElroy and Lucas, 2014). These economies have GNI per capita values slightly above the overall average for the Caribbean region, averaging 3.3 on the World Bank income classification.

Two other clusters also exhibit important specialization in tourism (Clusters 2 and 5). Cluster 5 has by far the best performing tourism sector, in terms of both overnight and cruise tourists. The cluster comprises small islands (i.e., Aruba, Bahamas, Cayman Islands and Netherlands Antilles) but cannot be strictly defined as SITEs because they also possess active offshore finance sectors. These economies have the highest average GNI per capita of all the Caribbean clusters (4.0) and are termed Highly Successful Tourism \& Finance Economies.

Tourism is also important in Cluster 2, although slightly below the overall Caribbean average. The cluster members however, cannot be described as SITEs since some are small island states (i.e., Barbados, Dominica and St Kitts \& Nevis) but the rest are relatively large mainland states (Belize, Costa Rica and Panama). They also have successful offshore finance sectors, large agriculture sectors (averaging 7.1 per cent of gross value added - GVA) and (unusually) substantial industry (11.0 per cent of GVA). These are therefore categorized as 'Relatively Diversified' economies.

The final two clusters are more easily recognizable. Cluster 3 comprises eight 'Resources \& Industry' economies, three of which are island states and the rest mainland states. Cluster 4 is dominated by mainland states, with the Dominican Republic and Haiti as (partial) island members, and has the lowest average GNI per capita in the region (1.8). The cluster is termed 'Traditional Economies' because its key sectors are agriculture and industry but members lack a significant presence in the more lucrative tertiary sector. 


\section{How Robust is the Cluster Analysis? The Extent of the Data Truncation Problem}

Analysis of the economic performance and structure of small Caribbean entities however, is hampered by severe data truncation, even for the highly restricted set of variables used here. Previous studies (e.g., Armstrong and Read, 2000, 2004) take advantage of two phenomena to address this problem. Virtually all of the omitted entities have highly specialized niche sectoral structures, such that their economies are much 'simpler' than their larger counterparts. This makes data collection from non-standard sources easier. Further, data for binary or ordinal variables can also be used. Details of how the original seven cluster variables and the non-standard data have been re-defined here using 'best judgement' is set out in Annex Table 1. This Section considers the sensitivity of the cluster analysis to the omission of eight associated territories.

The results of re-running the cluster analysis for all 36 Caribbean states and territories with the same seven variables (except for ordinal variables for agriculture and industry) are presented in Figure 2. To facilitate comparison with the initial analysis, similar cluster numbering is retained and a five-cluster solution is again examined. The summary statistics are presented in Table 4.

[Figure 2 here]

[Table 4 here]

Comparison of Tables 3 and 4 and Figures 1 and 2, reveals two key features. First, cluster membership in the two exercises is remarkably stable; virtually all of the original 28 states and territories in Figure 2 are in the same clusters as they were in Figure 1. Only two of the original cases - Mexico and Puerto Rico - switch between clusters; both from Cluster 3 (Resources \& Industry) to Cluster 1 (SITEs). Further scrutiny shows that these two cases are somewhat detached from the rest of Cluster 1 and close to forming a separate cluster with Montserrat. 'Unbundling' Cluster 1 into its two constituent parts; sub-Cluster 1a is selfevidently a SITE group of seven entities while Puerto Rico, Mexico and Montserrat form a relatively diversified sub-cluster with only manufacturing being relatively disproportionately represented. The characteristics of the five clusters are also unusually stable between the two analyses (Tables 4 \& 5).

[Table 5 here]

The principal conclusion of this test for cluster robustness is that the omission of the eight entities in the initial analysis is not a cause of major instability with respect to either the 
number or nature of the clusters identified. Interestingly, the previously omitted entities are to be found almost exclusively in Cluster 1 (SITEs) and Cluster 5 (Tourism \& Finance). Only French-Guiane appears elsewhere (Cluster 3 - Resources \& Industry). The implications of this robustness analysis are rather disquieting. Working with highly truncated datasets initially suggests that membership of Clusters 1 and 5 is very small (see Figure 1) when, in fact, it is actually much larger. These two clusters switch from being the two smallest clusters to two of the largest.

\section{Additional Characteristics of the Five Caribbean Clusters, 2007}

The characteristics of the five clusters can be analyzed further by examining a range of additional variables (Table 6). These are sub-divided into four categories: (a) geographical characteristics; (b) additional economic performance variables; (c) additional standard neoclassical growth model variables; and (d) additional tourism variables. Caution however, needs to be exercised since data could not be obtained for all of the entities in a given cluster. In these cases, the number on which the average value is based is shown in parentheses. Because Puerto Rico and Mexico are the least stable cases within the analysis, results are presented for both Cluster 1 as a whole and also for its two component sub-clusters (Clusters $1 \mathrm{a}$ and $1 b)$.

[Table 6 here]

Several features stand out in Table 6:

- The two most successful clusters in terms of GNI per capita are Clusters 1 (SITEs) and 5 (Tourism \& Finance), which contain exclusively small islands. Further, their average populations and land areas are the lowest of all five clusters but they also have the highest population densities. The high GNI per capita values are borne out by high life expectancy and growth rates 2000-07. Cluster 1 appears to exhibit high levels of out-migration (in 2007) in stark contrast to net in-migration in Cluster 5. The entities in both clusters generally perform very well in terms of other growth variables in the table. The additional tourism variables however, reveal an important difference: Cluster 5 entities are more dependent on North American tourists than those in Cluster 1, which attract a disproportionately large share from Europe.

- $\quad$ Cluster 2 (Relatively Diversified) comprises relatively small entities that are more remote from both North America and Europe as well as containing more mainland states than the two best performing clusters. These entities score highly on the 
additional growth variables, primarily because of their strong offshore finance sectors, but less well than Clusters 1 and 5. Their tourism sectors however, are relatively weak, with below average overall tourist numbers per thousand population and tourist expenditure values.

- $\quad$ Entities in Cluster 3 (Resources \& Industry) have the largest populations and areas but are also relatively remote from North America and Europe. Nevertheless, they exhibited strong growth rates 2000-07 and have high life expectancy but are not consistent success stories. They exhibit net out-migration and below average values for key growth model variables as well as weak tourism sectors and a slight overrepresentation of European tourists.

- Cluster 4 (Traditional) comprises relatively large states (second only in population and area to Cluster 3) that are remote from North America and Europe. Virtually all of the additional growth variables along with tourism are adverse. Unsurprisingly, these states have the lowest GNI per capita values.

The values for the additional variables are highly consistent with the original analysis and show clear differences in pattern among the clusters within the Caribbean region.

\section{The Performance of the Caribbean Clusters Post-2007}

This Section focuses on the comparative performance of Caribbean states in the period immediately after the global financial crisis through to 2014, with reference to their preexisting cluster membership. Year-on-year changes in real output for entities within each cluster are presented in Table 7. The least stable cluster members, Mexico and Puerto Rico, are again presented separately. The table is based upon the International Monetary Fund (IMF) World Economic Outlook database, April 2014, supplemented by miscellaneous additional (less harmonized) data from other sources (see Table 7, Footnote b). In some cases, similar data has been assembled, notably from IMF Country Reports. Elsewhere, nonharmonized national government data is drawn upon. Considerable caution must therefore be exercised in interpreting any results based upon the less harmonized data sources (shown in italics).

[Table 7 here]

The IMF data in Table 7 reveal a close link between initial cluster membership and the change in GDP post-2007. Cases of negative GDP growth are shown by shaded cells. Entities in Clusters 1 (SITEs) and 5 (Tourism \& Finance), which had the highest GNI per capita in 
2007, appear to have performed particularly badly. Their economies deteriorated much more severely than those in other clusters in 2009 and have recovered more slowly. The remaining clusters fared much less badly. These findings accord with more general appraisals of the cross-country effects of the crisis in the Latin America \& Caribbean region (e.g., IMF, 2013).

The changes in overall average cluster output 2007 to 2014 are shown in Table 8. The first column covers the period of declining GDP (2007-10) while the second marks the period of economic recovery (2010-14). The table reveals substantial differences between Clusters 1 (SITEs) and 5 (Tourism \& Finance) and the remaining three clusters. The former two declined more severely 2007-10 and also recovered much less quickly after 2010 than Clusters 2 (Relatively Diversified) and 3 (Resources \& Industry). Cluster 4 (Traditional) also suffered a severe decline 2007-2010 (-3.2 per cent) but recovered very strongly after 2010 (+17.6 per cent). Those entities in Cluster 1 appear to have suffered the most severe effects of the crisis, with the biggest GDP decline of all of the clusters 2007-2010 (-7.7 per cent) and the weakest recovery after 2010 (+6.4 per cent). Those in Cluster 5 also performed weakly. The two best performing clusters prior to the global crisis therefore experienced the biggest 'hits' after 2007 and have since experienced the most faltering recovery.

[Table 8 here]

With regard to the less harmonized data in Table 7 (in italics), the annual GDP changes for those entities initially omitted in Cluster 1 (SITEs) exhibit a remarkably similar pattern to those entities for which better quality IMF data are available. In all cases, an initial weakening of output growth in 2008 was followed by major declines in 2009 and then slow patchy recoveries since 2010 . The supplementary data also show a highly consistent pattern for Cluster 5 (Tourism \& Finance). Again, these entities appear to have been severely hit, particularly during 2009, with double digit output falls in the British Virgin Islands and the Turks \& Caicos Islands.

Two principal conclusions can be drawn from Tables 7 and 8 . The distinct pre-crisis clusters incorporating simple sectoral specialization yield groups of Caribbean entities which exhibit systematically different post-crisis output paths. Further, those clusters specializing in tourism (both stop-over and cruise) and offshore finance have performed particularly badly. Economies with rich natural resources and those with broader-based more traditional agriculture and manufacturing sectors appear to have weathered the crisis rather better, both during the initial downturn and the subsequent recovery. The lack of harmonized data for many non-sovereign entities in the region however, has acted to conceal the severity of the 
domestic impact of the crisis. The crisis and its consequences have thus led some to reassess their longer-term relationship with their metropole in spite of their special status (see Clegg et al., 2017).

Any interpretation of these results however, should not be overly deterministic given a degree of within-cluster variation. What is evident is therefore not solely a 'sectoral mix' effect. In Cluster 1 (SITEs), Guadeloupe performed better than other members. In Cluster 5 (Tourism \& Finance), Curaçao and Sint Maarten also performed better than the norm while the British Virgin Islands and the Turks \& Caicos have done a lot worse. Sectoral specialization alone therefore does not tell the whole story - there are other forces at work; local factors are also likely to have played a part (e.g., earthquakes in Haiti and governance issues in the Turks \& Caicos). Nevertheless, the patterns revealed in Tables 7 and 8 show that sectoral specialization has been an important factor in post-crisis economic performance.

Given the importance of trade to the smaller entities that are the principal focus of this paper, Table 9 shows: (a) current account balances (percentage of GDP); and (b) annual percentage changes in exports of goods and services. Only those states for which harmonized IMF data are available are included. Four principal findings stand out:

[Table 9 here]

- $\quad$ Entities in Cluster 1 (SITEs) entered the global financial crisis with the largest current account deficits. Those in Cluster 5 (Tourism \& Finance) also had deficits but these were much smaller. Many of the entities in Cluster 3 (Resources \& Industry) were running current account surpluses in 2008, while those in Clusters 2 (Relatively Diversified) and 4 (Traditional) lie in between with consistent relatively small, deficits. There are several possible reasons why Clusters 1 and 5 were able to sustain large current account deficits ahead of the crisis. These include the presence of offshore finance sectors and (for many) their associated territory status - both of which may have permitted larger than usual capital account inflows - but also, possibly, more profligate international borrowing and greater flows of migrant remittances.

- $\quad$ Most entities managed to reduce their current account deficits 2008-14, including those in both Clusters 1 and 5. Deficits across the region as of 2014 however, remained substantial; the post-crisis recovery proved to be long and drawn-out.

- The recovery of exports is critical for small trade-dependent economies. Changes in export volumes 2008-14 are also shown in Table 9. Entities in Clusters 1 and 5, in 
particular, have had a halting recovery, shown by falling export volumes. The strongest recovery has been among the 'Traditional' entities (Cluster 4), followed by Cluster 3 but entities in Cluster 2 have more closely resembled the sluggish export performance of Clusters 1 and 5.

- $\quad$ Entities in Cluster 3 were, initially, the least adversely affected by the crisis in 2008 , experiencing limited falls (if any) in exports. This reflected their reliance upon natural resources, several of which (e.g., oil and gas) experienced buoyant demand and global price rises at the time of the crisis and immediately afterwards. Since then, their recovery has been quite strong.

These conclusions adhere to findings regarding the country-specific effects of the crisis with respect to higher per capita incomes and trade openness as well as credit growth and current account deficits (Lane and Milesi-Ferretti, 2010).

Table 10 throws further light on the poor performance of the small tourist-dependent entities within Clusters 1 (SITEs) and 5 (Tourism \& Finance) during the initial crisis downturn and subsequent recovery. The first six columns show year-on-year changes in the volume of stop-over tourist arrivals (negative if shaded), while the final six columns show data for the important Caribbean cruise tourism market. These show the magnitude of the fall in stop-over tourism in 2009 in particular (with cruise tourism lagging somewhat into 2010) but also the fragility of the recovery in tourist numbers in the period immediately after the crisis, with most entities experiencing further falls in 2012 and 2013.

[Table 10 here]

Focusing on financial services and tourism has been a generally successful growth strategy for small economies globally; those in the Caribbean entered the global crisis in 2007 as the wealthiest of all the clusters in the region. The nature of the crisis however, meant that those specializing in financial services (Cluster 5) were particularly vulnerable to its effects. Further, the high dependence of both Clusters 1 and 5 on tourism flows from North America and Western Europe has not served them well, since these markets were particularly hard-hit by the global crisis and its aftermath and have since recovered relatively slowly. The Caribbean tourist-dependent clusters have therefore suffered and continue to do so; in 2009, tourist arrivals fell by 4.7 per cent compared to 3.9 per cent globally (United Nations World Tourism Organisation and Caribbean Tourism Organisation data). By 2013, arrivals had only risen by 1.8 per cent compared to global growth of 5.0 per cent (Caribbean Tourist Organisation, 2013). 


\section{Conclusion: the Impact of the 2008 Global Crisis On Small Caribbean Economies}

This paper investigates the impact of the 2008 global economic crisis on the Caribbean region, with a particular focus on its many small entities. Prior to the crisis, growth success and attainment of high per capita incomes (GNI) is shown to be strongly associated with their distinct sectoral structures specializing in offshore finance and tourism. This pattern of specialization however, rendered small entities in the Caribbean and elsewhere highly susceptible to the effects of the global crisis. Cluster analysis demonstrates that those entities in Clusters 1 (small island tourism economies - SITEs) and 5 (Tourism \& Finance) were hit hardest by the crisis and have recovered more slowly than other Caribbean economies. This pattern of sectoral specialization is the primary reason for these entities experiencing a worse downturn and more sluggish domestic recovery since 2008. In contrast to the preceding period, the magnitude of the impact of the global crisis on small entities in the Caribbean region - and, possibly, elsewhere - appears to have overwhelmed the positive effects of trade openness and regional/global integration as natural 'shock-absorbers'. Key indicators in many of the entities in Clusters 1 and 5, in particular, also increased their susceptibility to the global crisis; namely high income, open, developing economies with high credit growth and large trade deficits (Lane and Milesi-Ferretti, 2010). The first three factors however, are pervasive among many small entities as a direct result of their size. Openness to trade based upon output and export specialization, often founded upon offshore financial services and tourism, has long been regarded as a key element in the growth strategies of small economies, including those in the Caribbean region. The impact of the global crisis however, has highlighted the inherent risk of greater growth volatility arising from such a strategy in times of international economic turbulence. The major challenge for these entities is therefore to identify and implement more appropriate long-term growth strategies.

A variety of policy options have been proposed but it is important to recognize that, although the standard solution to these problems is diversification (of output, exports and export markets), the potential to do so is highly constrained by the structural characteristics of small economies. Specialization in scale-neutral niche income elastic activities has provided a partial, but ultimately insufficient, solution to growth volatility. One potential strategy is therefore to simply 'soldier on', reliant upon the slow revival of tourism volumes and confidence in financial services, in the hope of a steady, if painful, return to pre-2008 affluence. The global crisis however, has highlighted fundamental flaws in this strategy such that new growth-promoting policies are needed, possibly including greater state involvement 
(Bàrcena, 2010). Greater trade and integration with more dynamic emerging markets, such as Brazil, China and India, would reduce their heavy dependence on economic cycles in the US (Kouame and Reyes, 2011) as well as the metropoles of the many non-sovereign entities in the region (Clegg et al., 2017). OECD governments have been taking steps to clamp down on offshore tax avoidance and evasion, such that an over-reliance on financial services may not be a sustainable long-term growth strategy. Tourism is probably more dependable but many destinations remain wedded to traditional 'sun and sand' offers while the rapidly growing allinclusive and cruise tourism sectors tend to confer reduced local multiplier benefits. At the very least, small tourism-dependent entities probably need to adapt very quickly to this global trend. Nevertheless, many small entities have shown themselves to be very adept at moving quickly and effectively when their niche sectors are threatened. Those small Caribbean entities that are dependent upon tourism and financial services may therefore be facing the need to do so again.

\section{References}

Alesina, A., E. Spolaore and R. Wacziarg. 2005. "Trade, Growth and the Size of Countries." In Handbook of International Growth, Volume 1B, edited by P. Aghion and S.N. Durlauf, 1499-1542. Amsterdam: Elsevier.

Armstrong, H.W., R.J. de Kervenoael, X. Li, and R. Read. 1998. “A Comparison of the Economic Performance of Different Micro-States and Between Micro-States and Larger Countries." World Development 26 (4): 639-656.

Armstrong, H.W. and R. Read. 1998. "Trade and Growth in Small States: The Impact of Global Trade Liberalisation." The World Economy 21 (4): 563-585.

Armstrong, H.W. and R. Read. 2000. "Comparing the Economic Performance of Dependent Territories and Micro-States.” Economic Development \& Cultural Change 48: 285-306. Armstrong, H.W. and R. Read. 2002. "The Phantom of liberty?: Economic Growth and the Vulnerability of Small States.” Journal of International Development, 14 (3): 435-458. Armstrong, H.W. and R. Read. 2004. "Small States and Island States: Implications of Size, Location and Isolation for Prosperity." In On the Edge of the Global Economy, edited by J. Poot, 193-223. Cheltenham: Edward Elgar. 
Armstrong, H.W. and R. Read. 2006. "Insularity, Remoteness, Mountains and Archipelagos: A Pacific Perspective On the Problems Facing Small States.” Asia Pacific Viewpoint 47 (1): 77-90.

Ashoff, G. 1989. "Economic and Industrial Development Options for Small Third World Countries." Occasional Paper No. 91. Berlin: German Development Institute.

Bàrcena, A. 2010. Structural constraints on development in Latin America and the Caribbean: a post-crisis reflection. CEPAL Review. 100: 7-27.

Bhaduri A., A. Mukherji, and R. Sengupta 1982. "Problems of Long-Term Growth in Small Economies: A Theoretical Analysis." In Problems \& Policies in Small Economies, edited by B. Jalan, 39-68. Beckenham: Croom Helm for the Commonwealth Secretariat. Blazic-Metner B. and H. Hughes 1982. "Growth Experience of Small Economies.” In Problems \& Policies in Small Economies, edited by B. Jalan, 85-101. Beckenham: Croom Helm for the Commonwealth Secretariat.

Briguglio, L. 1995. "Small Island Developing States and Their Economic Vulnerabilities." World Development 23 (10): 1615-1632.

[British Virgin Islands]. 2012. Budget Address 2012. Road Town, BVI: Ministry of Finance. Caribbean Tourism Organisation. Tourism Statistics. http://www.onecaribbean.org/statistics (accessed April 2012).

Caribbean Tourism Organisation. 2013. Caribbean Tourism Review: Tourism Industry Update (accessed May 2014).

Cavallo, E.A. 2007. “Output Volatility and Openness to Trade.” Inter-American Development Bank. http://www.iadb.org/research/pub_hits.cfm?pub_id=WP604\&pub_file name=pubWP-604.pdf.

[Cayman Islands]. 2010. Annual National Accounts Report 2010. George Town: Government of Cayman Islands, Economic \& Statistics Office.

[Cayman Islands]. 2011a. $3^{\text {rd }}$ Quarter 2011 Economic Report. George Town: Government of Cayman Islands, Economic \& Statistics Office.

[Cayman Islands]. 2011b. Foreign Trade Report 2011. George Town: Government of Cayman Islands, Economic \& Statistics Office,

CIA. World Factbook (accessed April 2012).

Clegg, P., Daniel, J., Pantojas-Garcia, W., and Veendaal, W. 2017. “The global financial crisis and its aftermath: economic and political recalibration in the non-sovereign Caribbean.” Canadian Journal of Latin American \& Caribbean Studies. 42 (1): 84-104. 
Demas, W.G. 1965. The Economics of Development in Small Countries: With Special Reference to the Caribbean. Montreal: McGill University Press.

Dommen, E.C. and P.L. Hein. 1985. States, Microstates \& Islands. London: Croom Helm. Easterly, W. and A. Kraay 2000. "Small States, Small Problems? Income Growth and Volatility in Small States.” World Development 28 (11): 2013-2027.

Easterly, W., R. Islam, and J.E. Stiglitz 2001. "Shaken and Stirred: Explaining Growth Volatility.” In Annual World Bank Conference on Development Economics, edited by B. Pleskovic and N. Stern, 191-221. Washington DC: World Bank.

Eurostat. Statistics (accessed April 2012).

Everitt, B.S. 1993. Cluster Analysis. London: Heinemann Educational. 3rd ed.

[France]. Comtes Economiques Rapides. Paris: Institut National de la Statistique et de l'Etudes Economiques (accessed April 2012).

Holmes, F. 1986. "Development Problems of Small Countries." In Co-operation \& Development in the Asia Pacific Region: Relations Between Large \& Small Countries, edited by L.V. Castle and F. Holmes, 43-66. Tokyo: Japan Research Center.

IMF. 2010. Aruba: IMF Staff Report for the 2010 Article IV Consultation Discussions. IMF: Washington DC.

IMF. 2011. Netherlands Antilles: IMF Country Report No 11/342, IMF: Washington DC. IMF. 2012a. Anguilla: IMF Country Report No 12/8. Washington DC: IMF.

IMF. 2012b. Montserrat: IMF Country Report 12/9. Washington DC: IMF.

IMF. 2012c. Regional Economic Outlook: Western Hemisphere: Rebuilding Strength \& Flexibility. World Economic and Financial Surveys. Washington DC: IMF.

IMF. 2013. Caribbean Small States: Challenges of High Debt \& Low Growth. Washington DC: IMF.

IMF World Economic Outlook database (accessed April 2012).

Jalan, B., ed. 1982. Problems \& Policies in Small Economies. Beckenham: Croom Helm. Koren, M. 2007. "Volatility and Development." Quarterly Journal of Economics 122 (1): $243-287$.

Kouame, A., and Reyes, M.I. 2011. "The Caribbean region beyond the 2008-09 global financial crisis". Options for the Caribbean After the Global Financial Crisis Conference, Bridgetown, Barbados, 27-28 January 2011.

Kuznets, S. 1960. "The Economic Growth of Small States.” In The Economic Consequences of the Size of Nations, edited by E.A.G. Robinson, 14-32. London: Macmillan. 
Lane, P.R., and Milesi-Ferretti, G.M. 2010. "The cross-country incidence of the global crisis.” IMF Working Paper, WP10/171. Washington DC: IMF.

Lewis, W.A. 1955. The Theory of Growth \& Development. London: Allen \& Unwin.

Loayza, N.V., R. Rancière, L. Serven, and J. Ventura. 2007. "Macroeconomic Volatility and Welfare in Developing Countries: An Introduction." World Bank Economic Review 21 (3): $343-357$.

McElroy, J.L. 2003. "Tourism Development in Small Islands Across the World.” Geografiska Annaler 85 (4): 231-42.

McElroy, J.L. 2006. "Small Island Tourist Economies Across the Life Cycle." Asia Pacific Viewpoint 47 (1): 61-77.

McElroy, J.L. and H. Lucas. 2014. "The Significance of Geographic Location in Island Studies.” Island Studies 9 (2): 363-366.

Marcy, G. 1960. "How Far Can Foreign Trade and Customs Agreements Confer Upon Small Nations the Advantages of Larger Nations?" In The Economic Consequences of the Size of Nations, edited by E.A.G. Robinson, 265-281. London: Macmillan.

Raddatz, C. 2007. “Are External Shocks Responsible for the Instability of Output in LowIncome Countries?” Journal of Development Economics 84 (1): 155-187.

Ramey, G. and V. Ramey. 1995. "Cross-Country Evidence On the Link Between Volatility and Growth.” American Economic Review 85 (5): 1138-1151.

Read, R., H.W. Armstrong, and N. Picarelli. 2012. Binding Growth Constraints in Small Island Economies: Evidence Focusing On the Organisation of Eastern Caribbean States, Report for the Latin American \& Caribbean Section of the World Bank.

Robinson, E.A.G., ed. 1960. The Economic Consequences of the Size of Nations. London: Macmillan.

Rodrik, D. 1999. "Where Did All the Growth Go? External Shocks, Social Conflict and Growth Collapses.” Journal of Economic Growth 4 (4): 385-412.

Rose, A.K. 2006. “Size Doesn't Really Matter: In Search of a National Scale Effect.” Journal of the Japanese \& International Economies 20: 482-507.

Rose, A.K. and M.M. Spiegel. 2007. “Offshore Financial Centres: Parasites or Symbionts?” Economic Journal 117: 1310-1335.

Thomas, I. 1982. "The Industrialisation Experience of Small Economies.” In Problems \& Policies in Small Economies, edited by B. Jalan, 103-124. Beckenham: Croom Helm for the Commonwealth Secretariat. 
[Turks and Caicos Islands]. National Statistics. Cockburn Town: Department of Economic Planning and Statistics (accessed April 2012).

[United Kingdom]. Statistics. London: Foreign \& Commonwealth Office.

United Nations. Main Accounts Aggregates Database. New York: United Nations.

UNCTAD. 1997. The Vulnerability of Small Island Developing States in the Context of Globalization: Common Issues \& Remedies. Geneva: UNCTAD, SIDS.

UN World Tourism Organisation. 2011 Compendium of Tourism Statistics. http://statistics.unwto.org (accessed April 2012).

[US Virgin Islands]. 2011. Bureau of Economic Research Economic Review. Charlotte Amalie: Bureau of Economic Research.

[United States]. Statistics. Washington DC: Department of Interior Office for Insular Affairs, (accessed April 2012).

World Bank. World Development Indicators. Washington DC: World Bank (accessed April 2012).

World Bank. World Development Report (various issues). Washington DC: World Bank.

World Development. 1980. Special issue 8 (12).

World Development. 1993. Special issue 21 (2). 
Table 1: Caribbean States, Latin American States \& Associated Territories in the Initial Cluster Analysis

Entities Initially Included (28)

Entities Initially Excluded (8)

Antigua \& Barbuda

Anguilla (UK)

Aruba (NL)

Guadeloupe (F)

Bahamas

British Virgin Islands (UK)

Barbados

Martinique (F)

Belize

Cayman Islands (UK)

French-Guiane (F)

Colombia

Montserrat (UK)

Costa Rica

Turks \& Caicos Islands (UK)

Cuba

US Virgin Islands (US)

Dominica

Dominican Republic

Grenada

Guatemala

Guyana

Haiti

Honduras

Jamaica

Mexico

Netherlands Antilles (NL)

Nicaragua

Panama

Puerto Rico (US)

St Kitts \& Nevis

St Lucia

St Vincent \& the Grenadines

Suriname

Trinidad \& Tobago

Venezuela 
Table 2: Definition of Variables Used in the Cluster Analysis

GNIpc: GNI per capita, 2007, World Bank data used. Entities allocated to one of four World Bank income classes, producing an ordinal variable $(1=$ Lower Income - under $\$ 935 ; 2=$ Lower Middle Income $-\$ 936$ to $\$ 3,705 ; 3=$ Upper Middle Income $-\$ 3,706$ to $\$ 11,455 ; 4=$ High Income - over $\$ 11,456)$. \$US throughout. This is an ordinal version of GNI per capita, chosen to maximize number of very small states in data set. 'Key Indicators for Other Economies' table in World Bank, World Development Reports (especially 2009), the main source for the very small states. Data are not at PPP.

AGRIC: Agriculture, Forestry \& Fisheries as percentage of GVA, 2007. UN Main Accounts Aggregates Database. National currency values. Continuous variable.

INDUST: Industry (including manufacturing, construction, mining and utilities) as percentage of GVA. Source as AGRIC. Continuous variable.

TOURISTS: Caribbean Tourism Organisation (CTO)/World Tourism Organisation (UNWTO) data used, 2007. Data are numbers of tourist arrivals per 1,000 population; 2007 population figures used.

CRUISE: CTO/UNWTO data used, 2007. Cruise visitors per 1,000 population; 2007 population data. No data for Guyana; cruise tourists assumed to be zero.

FINAN: Binary variable for the presence/absence of an offshore finance center. Rose and Spiegel (2007) list used.

RESOUR: Binary variable for presence/absence of a major export-earning resource. Belize (oil, timber, fish); French-Guiane (timber, minerals, oil); Guyana (fish, timber, bauxite); Jamaica (bauxite and alumina); Suriname (alumina, gold, oil, timber, fish); Trinidad \& Tobago (oil \& gas); Cuba (oil, nickel). Excludes agricultural resources and 'green' environment resources (e.g., beaches, land area, mountains) or built environment. Comprises oil \& gas, other minerals, fish and timber resources. Variable is authors' own construction drawing on UK data and government statistical websites and publications. Rough rule of thumb of approximately 10 per cent or more of export earnings from the resources as the threshold value. 
Table 3: Cluster Variable Scores in the Five-Cluster Solution, 28-Case Analysis ${ }^{\mathrm{a}}$

\begin{tabular}{|c|c|c|c|c|c|c|}
\hline Cluster Number & 1 & 2 & 3 & 4 & 5 & All \\
\hline Cluster Variable & 'SITEs' & $\begin{array}{l}\text { Relatively } \\
\text { Diversified }\end{array}$ & $\begin{array}{l}\text { Resources \& } \\
\text { Industry }\end{array}$ & Traditional & $\begin{array}{l}\text { Highly Successful } \\
\text { Tourism \& Finance }\end{array}$ & \\
\hline \multicolumn{7}{|l|}{ GNI per capita, 2007} \\
\hline (ordinal, 1-4) & 3.3 & 3.2 & 3.1 & 1.8 & 4.0 & 3.0 \\
\hline Agriculture, 2007 (\% GVA) & 4.1 & 7.1 & 4.0 & 15.3 & 1.0 & 6.7 \\
\hline Industry, 2007 (\% GVA) & 4.2 & 11.0 & 25.6 & $\mathbf{1 7 . 3}$ & 3.7 & 14.5 \\
\hline $\begin{array}{l}\text { Overnight tourism arrivals, } 2007 \\
\text { (numbers per } 1,000 \text { population) }\end{array}$ & 1,706 & 1,225 & 342 & 165 & 5,466 & 1,420 \\
\hline Cruise tourism, 2007 (numbers & & & & & & \\
\hline per 1,000 population) & 3,849 & 2,442 & 118 & 24 & 13,682 & 3,066 \\
\hline $\begin{array}{l}\text { Offshore finance (binary - Rose } \\
\text { and Spiegel, 2007) (\% of states) }\end{array}$ & 0 & 100.0 & 0 & 0 & 100.0 & 35.7 \\
\hline $\begin{array}{l}\text { Resource endowment } \\
\text { (binary) (\% of states) }\end{array}$ & 0 & 16.7 & 75.0 & 16.7 & 0 & 28.6 \\
\hline Number of cases (n) & 4 & 6 & 8 & 6 & 4 & 28 \\
\hline
\end{tabular}

a, numbers in bold indicate individual cluster values greater than the 28-cluster average (shown in 'All'). 
Table 4: Cluster Variable Scores in the Five-Cluster Solution, 36-Case Analysis ${ }^{\mathrm{a}}$

\begin{tabular}{|c|c|c|c|c|c|c|}
\hline Cluster Number & 1 & 2 & 3 & 4 & 5 & All \\
\hline \multirow[t]{2}{*}{ Cluster Variable } & 'SITEs' & Relatively & Resources \& & Traditional & Highly Successful & \\
\hline & & Diversified & Industry & & Tourism \& Finance & \\
\hline \multicolumn{7}{|l|}{ GNI per capita, 2007} \\
\hline (ordinal, 1-4) & 3.5 & 3.2 & 3.1 & 1.8 & 4.0 & 3.2 \\
\hline Agriculture, 2007 (ordinal, 1-7) & 1.1 & 2.0 & 1.4 & 3.7 & 1.0 & 1.7 \\
\hline Industry, 2007 (ordinal, 1-7) & 2.8 & 2.7 & 4.3 & 4.0 & 1.6 & 3.0 \\
\hline \multicolumn{7}{|l|}{ Overnight tourism arrivals, 2007} \\
\hline (numbers per 1,000 population) & 1,723 & 1,225 & 294 & 165 & 6,984 & 2,125 \\
\hline \multicolumn{7}{|l|}{ Cruise tourism, 2007 (numbers } \\
\hline per 1,000 population) & 1,652 & 2,442 & 73 & 24 & 14,877 & 3,777 \\
\hline \multicolumn{7}{|l|}{ Offshore finance (binary - Rose } \\
\hline and Spiegel, 2007) (\% of states) & 0 & 100.0 & 0 & 0 & 85.7 & 33.3 \\
\hline \multicolumn{7}{|l|}{ Resource endowment } \\
\hline (binary) (\% of states) & 0 & 16.7 & 100.0 & 16.7 & 0 & 25.0 \\
\hline Number of cases (n) & 10 & 6 & 7 & 6 & 7 & 36 \\
\hline
\end{tabular}

a , numbers in bold indicate individual cluster values greater than the 28-cluster average (shown in 'All'). 
Table 5: Unbundling Cluster 1 into Two Constituent Sub-Clusters ${ }^{\mathrm{a}}$

\begin{tabular}{cccc} 
Cluster & $1 a$ & $1 b$ & All Clusters \\
Cluster Variable & SITEs & Industrial & \\
\hline GNI per capita, 2007 (ordinal 1-4) & $\mathbf{3 . 5}$ & $\mathbf{3 . 3}$ & 1.7 \\
Agriculture, 2007 (ordinal, 1-7) & 1.1 & 1.0 & 3.0 \\
$\begin{array}{l}\text { Manufacturing, 2007 (ordinal, 1-7) } \\
\text { Overnight tourism arrivals, 2007 } \\
\text { (numbers per 1,000 population) }\end{array}$ & 1.6 & $\mathbf{5 . 7}$ & 2,125 \\
$\begin{array}{c}\text { Cruise tourism, 2007 (numbers } \\
\text { per 1,000 population) }\end{array}$ & $\mathbf{2 , 1 3 3}$ & 925 & 3,783 \\
$\begin{array}{l}\text { Offshore finance (binary - Rose and } \\
\text { Spiegel) (\% of states) }\end{array}$ & 0 & 144 & 33.3 \\
$\begin{array}{l}\text { Resource endowment (binary) } \\
\text { (\% of states) }\end{array}$ & 0 & 0 & 25.0 \\
\begin{tabular}{l} 
Number of cases \\
\hline
\end{tabular} & 7 & 3 & 10 \\
\hline
\end{tabular}

a numbers in bold indicate individual cluster values greater than the 28 -cluster average (shown in 'All'). 
Table 6: Non-Cluster Variable Scores in the Five-Cluster Solution, 28-Case Analysis ${ }^{\text {a, b }}$

\begin{tabular}{|c|c|c|c|c|c|c|}
\hline Cluster Number & 1 & 2 & 3 & 4 & 5 & All \\
\hline Cluster Variable & ‘SITEs' & $\begin{array}{l}\text { Relatively } \\
\text { Diversified }\end{array}$ & $\begin{array}{l}\text { Resources \& } \\
\text { Industry }\end{array}$ & Traditional & $\begin{array}{l}\text { Highly Successful } \\
\text { Tourism \& Finance }\end{array}$ & \\
\hline \multicolumn{7}{|l|}{ 1. Geographical Characteristics } \\
\hline Island (\% cases) & 100.0 & 50.2 & 50.0 & 33.3 & 100.0 & 60.7 \\
\hline Archipelago (\% cases) & $\mathbf{5 0 . 0}$ & 16.7 & 25.0 & 0.0 & $\mathbf{7 5 . 0}$ & 28.6 \\
\hline Population (persons, 2007) & 116,675 & $1,262,886$ & $22,969,536$ & $7,069,905$ & 170,329 & $8,389,323$ \\
\hline Area $(\mathrm{sq} \mathrm{km})$ & 449 & 25,154 & 539,609 & 107,132 & 3,797 & 183,128 \\
\hline $\begin{array}{l}\text { Population density (persons per } \\
\text { sq km) }\end{array}$ & 261.7 & 174.3 & 145.5 & 124.1 & 263.0 & 180.5 \\
\hline $\begin{array}{l}\text { Mountainous ( } \% \text { cases over } 50 \% \\
\text { land area mountainous) }\end{array}$ & $\mathbf{7 5 . 0}$ & $\mathbf{5 0 . 0}$ & 37.5 & 66.7 & 25.0 & 50.0 \\
\hline Sovereign $(\%$ cases $)$ & 100.0 & 100.0 & 87.5 & 100.0 & 25.0 & 85.7 \\
\hline $\begin{array}{l}\text { Distance to US (Washington DC - } \\
\mathrm{km} \text { ) }\end{array}$ & 3,159 & 3,076 & 3,007 & 2,959 & 2,451 & 2,954 \\
\hline Distance to Europe (Brussels - km) & 7,103 & 7,926 & 7,847 & 8,233 & 7,576 & 7,802 \\
\hline \multicolumn{7}{|c|}{ 2. Additional Economic Performance Measures } \\
\hline $\begin{array}{l}\text { Growth rate of absolute GDP, } \\
2000-07(\%)\end{array}$ & 3.9 & 3.9 & 4.7 & 3.4 & $\begin{array}{c}1.4 \\
(1 / 4)\end{array}$ & $\begin{array}{c}3.9 \\
(25 / 28)\end{array}$ \\
\hline Life expectancy (years at birth) & $\begin{array}{l}73.7 \\
(3 / 4)\end{array}$ & $\begin{array}{l}76.3 \\
(4 / 6)\end{array}$ & 73.6 & 69.5 & $\begin{array}{l}74.5 \\
(2 / 4)\end{array}$ & $\begin{array}{c}73.1 \\
(23 / 28)\end{array}$ \\
\hline $\begin{array}{l}\text { Net migration per } 1,000 \text { population } \\
(2000-06 \text { average })\end{array}$ & $\begin{array}{l}-32.8 \\
(3 / 4)\end{array}$ & $\begin{array}{c}4.7 \\
(4 / 6)\end{array}$ & -15.2 & -27.0 & $\begin{array}{l}48.4 \\
(2 / 4)\end{array}$ & $\begin{array}{l}-11.6 \\
(23 / 28)\end{array}$ \\
\hline
\end{tabular}


3. Additional Growth Theory Variables

GNI per capita of adjacent states,

Average (ordinal, 1-4)

3.6

3.2

27.7

2.9

2.7

3.2

42.1

3.1

Investment

100.7

116.8

83.1

$(1 / 4)$

Openness (trade/GDP)

23.1

14.8

9.8

84.4

$(25 / 28)$

Government consumption (\%

share of GDP)

Inflation rate (CPI measure, \%

95.3

per annum)

Inflation rare (GDP deflator, \%

per annum

8.5

Colonizer state growth rate

(ordinal, 1-4)

4. Additional Tourism Variables

Tourist expenditure (\$US per capita) $\mathbf{1 , 9 1 0}$

North America tourist share (\%)

35.8

1,460

$309 \quad 140$

$(5 / 6)$

$(5 / 6)$
46.3

47.6

(5/6)

26.5

12.2

Europe tourist share (\%)

33.3

18.9

$(5 / 6)$

Number of cases (n)

4

8

$\begin{array}{cc}\mathbf{7 , 0 9 5} & 1,776 \\ & (27 / 28) \\ \mathbf{7 2 . 3} & 48.1 \\ & (27 / 28) \\ 12.2 & 20.8 \\ & (27 / 28) \\ 4 & 28\end{array}$

a , numbers in bold indicate individual cluster values greater than the 28-cluster average (shown in 'All').

$\mathrm{b}$, figures in parentheses indicate, where the data set is incomplete, the number of observations and the total number of states in group. 
Table 7: Changes in Caribbean Real Output (GDP) by Cluster, 2008-11 (\%) ${ }^{\text {a, b }}$

\begin{tabular}{|c|c|c|c|c|c|c|c|}
\hline Cluster & 2008 & 2009 & 2010 & 2011 & 2012 & 2013 & 2014 \\
\hline \multicolumn{8}{|l|}{ 1. SITES } \\
\hline Antigua \& Barbuda & 1.5 & -10.7 & 8.6 & -2.1 & 2.8 & 0.5 & $1.6^{\mathrm{c}}$ \\
\hline Grenada & 0.9 & -6.6 & -0.5 & 0.8 & -1.8 & 1.5 & $1.1^{\mathrm{c}}$ \\
\hline St Lucia & 4.7 & -0.1 & -0.7 & 1.4 & -1.3 & -1.5 & $0.3^{\mathrm{c}}$ \\
\hline $\begin{array}{l}\text { St Vincent \& the } \\
\text { Grenadines }\end{array}$ & -0.5 & -2.0 & -2.3 & 0.3 & 1.5 & 2.1 & $2.3^{\mathrm{c}}$ \\
\hline Anguilla & -0.3 & -14.5 & -4.9 & -1.2 & -2.2 & & \\
\hline Guadeloupe & 1.1 & -0.8 & 4.3 & 2.7 & 2.1 & & \\
\hline Martinique & -0.3 & -2.1 & 4.5 & 1.2 & 0.7 & & \\
\hline Montserrat & 4.5 & -0.5 & -3.6 & 2.0 & 1.4 & & \\
\hline \multicolumn{8}{|l|}{ 2. Relatively Diverse } \\
\hline Barbados & 0.3 & -4.1 & 0.2 & 0.8 & 0.0 & $-0.7^{c}$ & $-1.2^{\mathrm{c}}$ \\
\hline Belize & 3.8 & 0.3 & 3.1 & 3.0 & 4.0 & $1.6^{\mathrm{c}}$ & $2.5^{\mathrm{c}}$ \\
\hline Costa Rica & 2.7 & -1.0 & 5.0 & 4.5 & 5.1 & $3.5^{\mathrm{c}}$ & $3.8^{\mathrm{c}}$ \\
\hline Dominica & 7.8 & -1.1 & 1.2 & 0.2 & -1.1 & 0.8 & $1.7^{\mathrm{c}}$ \\
\hline Panama & 10.1 & 3.9 & 7.5 & 10.9 & 10.8 & $8.0^{\mathrm{c}}$ & $7.2^{\mathrm{c}}$ \\
\hline St Kitts \& Nevis & 3.4 & -3.8 & -3.8 & -1.9 & -0.9 & 1.7 & $2.7^{c}$ \\
\hline \multicolumn{8}{|l|}{$\begin{array}{l}\text { 3. Resource Rich \& } \\
\text { Industrial }\end{array}$} \\
\hline Cuba & 4.1 & 1.4 & 2.4 & 2.8 & 3.0 & & \\
\hline Colombia & 3.5 & 1.7 & 4.0 & 6.6 & 4.2 & $4.3^{\mathrm{c}}$ & $4.5^{\mathrm{c}}$ \\
\hline Jamaica & -0.8 & -3.3 & -1.4 & 1.4 & -0.5 & $0.5^{\mathrm{c}}$ & $1.3^{\mathrm{c}}$ \\
\hline Suriname & 4.1 & 3.0 & 4.2 & 5.3 & $4.8^{\mathrm{c}}$ & $4.7^{\mathrm{c}}$ & $4.0^{\mathrm{c}}$ \\
\hline Trinidad \& Tobago & 3.4 & -4.4 & 0.2 & -2.6 & $1.2^{\mathrm{c}}$ & $1.6^{\mathrm{c}}$ & $2.2^{\mathrm{c}}$ \\
\hline Venezuela & 5.3 & -3.2 & -1.5 & 4.2 & $5.6^{\mathrm{c}}$ & $1.0^{\mathrm{c}}$ & $-0.5^{\mathrm{c}}$ \\
\hline French-Guiane & 3.4 & 4.6 & 3.7 & 6.5 & 4.7 & & \\
\hline Mexico & 1.4 & -4.7 & 5.1 & 4.0 & $3.9^{\mathrm{c}}$ & $1.1^{\mathrm{c}}$ & $3.0^{\mathrm{c}}$ \\
\hline Puerto Rico & -2.0 & -0.4 & -0.3 & 0.5 & -0.8 & & \\
\hline \multicolumn{8}{|l|}{ 4. Traditional } \\
\hline Dominican Republic & 5.3 & 3.5 & 7.8 & 4.5 & 3.9 & 4.1 & $4.5^{\mathrm{c}}$ \\
\hline Guatemala & 3.3 & 0.5 & 2.9 & 4.2 & 3.0 & $3.5^{\mathrm{c}}$ & $3.5^{\mathrm{c}}$ \\
\hline Guyana & 2.0 & 3.3 & 4.4 & 5.4 & 4.8 & $4.8^{\mathrm{c}}$ & $4.3^{\mathrm{c}}$ \\
\hline Haiti & 0.8 & 3.1 & -5.5 & 5.5 & 2.9 & 4.3 & $4.0^{\mathrm{c}}$ \\
\hline Honduras & 4.2 & -2.4 & 3.7 & 3.8 & 3.9 & $2.6^{\mathrm{c}}$ & $3.0^{\mathrm{c}}$ \\
\hline Nicaragua & 4.0 & -2.2 & 3.6 & 5.4 & 5.2 & $4.2^{\mathrm{c}}$ & $4.0^{\mathrm{c}}$ \\
\hline \multicolumn{8}{|l|}{$\begin{array}{l}\text { 5. Highly Successful } \\
\text { Tourism \& Finance }\end{array}$} \\
\hline Aruba & -2.3 & -8.5 & -3.3 & 0.3 & -1.2 & & \\
\hline Bahamas & -2.3 & -4.2 & 1.0 & 1.7 & 1.8 & $1.9^{\mathrm{c}}$ & $2.3^{\mathrm{c}}$ \\
\hline Cayman Islands & -0.4 & -7.2 & -2.9 & 0.9 & & & \\
\hline Netherlands Antilles & 2.0 & -0.2 & -0.3 & 0.2 & 0.2 & & \\
\hline US Virgin Islands & 0.3 & -5.5 & 1.7 & -6.6 & -13.2 & & \\
\hline British Virgin Islands & -0.6 & 3.9 & 1.3 & -1.6 & -4.5 & & \\
\hline Turks \& Caicos Islands & 8.3 & 19.6 & 1.0 & 4.1 & 0.7 & & \\
\hline & & & & & & & \\
\hline
\end{tabular}


Notes: a , Data from IMF, World Economic Outlook database, April 2014 (expenditure based GDP at constant prices, country specific base years). Data shown in italics from other, miscellaneous sources -hence less reliable and not for the full time series.

b, Sources for data shown in italics as follows: Anguilla, Montserrat, Cuba, Puerto Rico. Aruba, Netherlands Antilles, British Virgin Islands and Turks \& Caicos Islands all from UN National Main Accounts Database. GDP at constant prices in national currencies. Some estimation used by UN where incomplete data series. Cayman Islands: Economic \& Statistical Office of Cayman Islands estimates, at 2007 prices. US Virgin Islands: US Bureau of Economic Research (real GDP growth estimated at August 2013). Guadeloupe, Martinique and French-Guiane: French Institut National de la Statistique et de l'Etudes Economique (INSEE) - PIB at market prices.

c, IMF staff estimates.

d, Shaded cells show declining GDP. 
Table 8: Average Change in Cluster GDP, 2007-10 and 2010-14 (\%)

\begin{tabular}{|l|c|c|c|}
\hline Cluster & $\mathbf{2 0 0 7 - 1 0}$ & $\mathbf{2 0 1 0 - 1 4}$ & $\begin{array}{c}\text { Number of } \\
\text { cases }\end{array}$ \\
\hline $\begin{array}{l}\text { 1. SITEs } \\
\text { 2. Relatively Diverse }\end{array}$ & -7.7 & +6.4 & 4 (of 8$)$ \\
\hline $\begin{array}{l}\text { 3. Resource Rich \& } \\
\text { Industrial }\end{array}$ & +1.9 & +12.1 & 6 (of 6) \\
\hline $\begin{array}{l}\text { 4. Traditional } \\
\text { 5. Highly Successful } \\
\text { Tourism \& Finance }\end{array}$ & +3.1 & +11.4 & 5 (of 7) \\
\hline
\end{tabular}

Notes: 1, Not annual averages. Figures show GDP absolute change over the two periods, as percentage of base year GDP. Note different lengths of the two time periods.

2 , Unweighted averages of cluster member countries.

3, Shaded cells show declining GDP. 
Table 9: Changes in Caribbean Current Account Balances \& Export Volumes by Cluster, 2008-14 a, b

Current Account Balance (\% of GDP)

Export Volume Change (\%)

\begin{tabular}{|c|c|c|c|c|c|c|c|c|c|c|c|c|c|c|}
\hline Cluster & 2008 & 2009 & 2010 & 2011 & 2012 & 2013 & 2014 & 2008 & 2009 & 2010 & 2011 & 2012 & 2013 & 2014 \\
\hline \multicolumn{15}{|l|}{ 1. SITES } \\
\hline Antigua \& Barbuda & -26.7 & -14.0 & -14.7 & -10.4 & -14.0 & -13.8 & -12.3 & 1.0 & -12.2 & -3.4 & 3.5 & -0.3 & -3.3 & 1.0 \\
\hline Grenada & -28.0 & -22.2 & -22.1 & -21.8 & -19.2 & -27.2 & -22.6 & -5.4 & -6.8 & -8.7 & 4.8 & -7.4 & -4.0 & 6.2 \\
\hline St Lucia & -28.7 & -11.6 & -16.2 & -18.8 & -12.8 & -11.8 & -11.4 & 7.7 & 8.4 & 6.5 & -7.5 & -5.6 & 2.8 & 2.8 \\
\hline $\begin{array}{l}\text { St Vincent \& the } \\
\text { Grenadines }\end{array}$ & -33.1 & -29.2 & -30.6 & -29.4 & -27.8 & -28.9 & -30.7 & 7.7 & -13.5 & 1.8 & -12.3 & 3.3 & 4.8 & 5.0 \\
\hline \multicolumn{15}{|c|}{ 2. Relatively Diverse } \\
\hline Barbados & -10.7 & -6.8 & -5.8 & -11.4 & -10.1 & -11.4 & -7.8 & -5.1 & -10.9 & 4.5 & -0.6 & -5.5 & -3.2 & 3.0 \\
\hline Belize & -10.6 & -4.9 & -2.4 & -1.1 & -2.2 & -4.2 & -4.5 & 1.1 & -6.6 & 7.9 & 5.7 & 8.3 & -2.0 & -0.9 \\
\hline Costa Rica & -9.3 & -2.0 & -3.5 & -5.3 & -5.3 & -5.0 & -5.1 & -2.0 & -6.0 & 5.5 & 5.4 & 9.5 & 3.6 & 6.5 \\
\hline Dominica & -28.7 & -22.7 & -17.4 & -14.5 & -18.9 & -17.0 & -17.7 & -3.4 & 2.3 & 7.5 & -0.2 & -13.0 & 5.7 & 5.1 \\
\hline Panama & -10.9 & -0.7 & -11.4 & -15.9 & -10.6 & -11.9 & -11.5 & 17.0 & 15.2 & -8.0 & 12.1 & 25.0 & 5.3 & 6.6 \\
\hline St Kitts \& Nevis & -27.3 & -27.3 & -21.5 & -15.7 & -11.9 & -8.5 & -17.4 & -19.9 & -0.9 & 1.6 & -6.5 & 5.9 & 16.7 & -16.5 \\
\hline \multicolumn{15}{|l|}{$\begin{array}{l}\text { 3. Resource Rich \& } \\
\text { Industrial }\end{array}$} \\
\hline Colombia & -2.8 & -2.1 & -3.0 & -2.9 & -3.2 & -3.3 & -3.3 & 6.6 & 6.7 & 1.2 & 13.8 & 4.5 & 1.8 & 4.4 \\
\hline Jamaica & -17.7 & -11.0 & -8.7 & -13.4 & -13.0 & -10.4 & -8.6 & -9.4 & 15.6 & -15.9 & -9.4 & 6.5 & 11.6 & 11.1 \\
\hline Suriname & 9.2 & 0.3 & 6.4 & 5.8 & 0.6 & -4.7 & -4.5 & 14.7 & -8.1 & 29.9 & 6.4 & 5.8 & -6.3 & -8.5 \\
\hline Trinidad \& Tobago & 30.5 & 8.5 & 20.3 & 12.4 & 4.9 & 10.2 & 10.1 & 20.0 & -38.2 & 5.8 & 13.4 & -10.7 & 18.7 & -2.9 \\
\hline Venezuela & 10.2 & 0.7 & 3.0 & 7.7 & 2.9 & 2.7 & 2.4 & -1.0 & -13.7 & -12.9 & 4.7 & 1.6 & -6.5 & 0.3 \\
\hline Mexico & -1.8 & -0.9 & -0.3 & -1.1 & -1.3 & -1.8 & -1.9 & 0.5 & -13.5 & 21.6 & 7.5 & 3.5 & 2.0 & 5.1 \\
\hline \multicolumn{15}{|l|}{ 4. Traditional } \\
\hline Dominican Republic & -9.9 & -5.0 & -8.4 & -7.9 & -6.8 & -4.2 & -4.5 & -4.7 & -8.4 & 12.2 & 8.7 & 6.9 & 6.2 & 7.2 \\
\hline Guatemala & -3.6 & 0.7 & -1.4 & -3.4 & -2.6 & -3.0 & -2.6 & 4.1 & -2.0 & 3.7 & 2.1 & 2.3 & 2.4 & 4.9 \\
\hline Guyana & -13.7 & -9.1 & -9.6 & -13.1 & -13.3 & -17.9 & -18.3 & -7.7 & 0.2 & -4.6 & 6.1 & 9.7 & 2.4 & 4.9 \\
\hline Haiti & -3.1 & -1.9 & -1.5 & -4.3 & -5.4 & -6.5 & -5.8 & 10.0 & 20.4 & -4.6 & 20.8 & 3.0 & 14.3 & 7.8 \\
\hline Honduras & -15.4 & -3.8 & -4.3 & -8.0 & -8.6 & -8.8 & -7.4 & 0.1 & -17.1 & 19.0 & 10.1 & 10.6 & -0.8 & 3.8 \\
\hline Nicaragua & -18.4 & -8.6 & -9.7 & -13.2 & -12.9 & -13.2 & -12.7 & 12.7 & 3.6 & 18.7 & 9.2 & 8.8 & 11.4 & 11.8 \\
\hline
\end{tabular}




\begin{tabular}{|l|l|l|l|l|l|l|l|l|l|l|l|l|l|l|}
\hline $\begin{array}{l}\text { 5. Highly Successful } \\
\text { Tourism \& Finance }\end{array}$ & & & & & & & & & & & & & & \\
\hline Bahamas & -10.6 & -10.4 & -10.1 & -15.3 & -18.4 & -19.6 & -14.7 & & -4.2 & -20.2 & 2.9 & -1.0 & 9.4 & 2.4 \\
\hline
\end{tabular}

Notes: a, Exports of both goods and services included.

, Data are from IMF, World Economic Outlook database, April 2014. Data in italics IMF staff estimates. 
Table 10: Changes in Tourism for Clusters 1 (SITEs) \& 5 (Highly Successful Tourism and Finance) Economies, 2007-13 ${ }^{\mathrm{a}}$

Tourist (Stop-Over) Arrivals: \% Change

Cruise Passengers: \% Change

\begin{tabular}{|c|c|c|c|c|c|c|c|c|c|c|c|c|}
\hline Cluster & 2008 & 2009 & 2010 & 2011 & 2012 & 2013 & 2008 & 2009 & 2010 & 2011 & 2012 & 2013 \\
\hline \multicolumn{13}{|l|}{ SITES } \\
\hline Antigua \& Barbuda & 1.5 & -11.8 & -1.9 & 5.0 & 2.3 & -1.2 & -13.7 & 22.7 & -21.8 & 8.8 & -9.1 & -3.1 \\
\hline Grenada & 0.4 & -12.5 & -2.6 & 7.1 & -5.1 & 0.9 & 8.3 & 16.1 & -2.8 & 24.5 & -21.7 & -18.6 \\
\hline St Lucia & 2.9 & -5.8 & 9.9 & 2.1 & -1.8 & 3.9 & 1.5 & 12.8 & -4.2 & -5.9 & -9.3 & 3.9 \\
\hline $\begin{array}{l}\text { St Vincent \& the } \\
\text { Grenadines }\end{array}$ & -6.2 & -10.3 & -3.9 & 1.9 & 0.7 & -3.5 & -19.3 & 28.2 & -25.8 & -19.9 & -13.4 & 7.8 \\
\hline Anguilla & -12.1 & -15.2 & 7.1 & 6.1 & -1.6 & 6.8 & - & - & - & - & - & - \\
\hline Guadeloupe & na & na & na & na & na & na & na & na & na & na & na & na \\
\hline Martinique & -4.3 & -7.9 & 7.9 & 4.2 & -1.8 & 0.3 & 21.5 & -19.9 & 7.0 & -44.9 & 127.3 & 11.0 \\
\hline Montserrat & -5.0 & -14.3 & -5.2 & -9.8 & 35.5 & -1.5 & - & - & - & - & - & - \\
\hline \multicolumn{13}{|l|}{$\begin{array}{l}\text { Highly Successful } \\
\text { Tourism \& } \\
\text { Finance }\end{array}$} \\
\hline Aruba & 7.1 & -1.7 & 7.1 & 5.4 & 4.0 & 8.3 & 15.4 & 9.1 & -6.2 & 5.4 & -2.9 & 18.2 \\
\hline Bahamas & -4.3 & -9.3 & 3.3 & -1.7 & 5.6 & -4.1 & -3.7 & 13.8 & 17.0 & 9.2 & 6.6 & 6.2 \\
\hline Cayman Islands & 3.9 & -10.2 & 6.0 & 7.2 & 4.1 & 7.4 & -9.5 & -2.1 & 5.1 & -12.3 & 7.6 & -8.7 \\
\hline \multicolumn{13}{|l|}{$\begin{array}{c}\text { Netherlands } \\
\text { Antilles: }\end{array}$} \\
\hline - $\quad$ Curaçao & 36.4 & -10.3 & -6.8 & 14.2 & 7.5 & 4.9 & -6.6 & 37.2 & -9.5 & 4.7 & 7.6 & 41.4 \\
\hline - $\quad$ Sint Maarten & 1.3 & -7.4 & 0.7 & -4.2 & 7.6 & 2.3 & -5.4 & -9.7 & 24.5 & 9.5 & 5.9 & 1.5 \\
\hline US Virgin Islands & -1.5 & -2.5 & 3.8 & -1.8 & 8.6 & -4.7 & -8.4 & -9.9 & 17.5 & 8.1 & -5.2 & 4.9 \\
\hline $\begin{array}{l}\text { British Virgin } \\
\text { Islands }\end{array}$ & -3.4 & -10.7 & 7.0 & 2.2 & 4.0 & 1.2 & -0.6 & -7.2 & -5.4 & -3.3 & -19.4 & -5.9 \\
\hline $\begin{array}{l}\text { Turks \& Caicos } \\
\text { Islands }\end{array}$ & & & $\begin{array}{c}2007 / 10= \\
6.1\end{array}$ & 35.4 & -17.6 & -0.4 & & & $\begin{array}{c}2007 / 10= \\
62.6\end{array}$ & 6.1 & -18.5 & 15.1 \\
\hline
\end{tabular}

Notes: a. Caribbean Tourism Organisation data used except Turks \& Caicos Islands (Turks \& Caicos Tourist Board data). 
Annex Table 1: Details of Extension of the Cluster Variables to 36 Entities

GNIpc: GNI per capita, 2007, World Bank data. Entities allocated to one of four ordinal classes designated by the World Bank ( $1=$ Lower Income - under $\$ 935 ; 2=$ Lower Middle Income $\$ 936$ to $\$ 3,705 ; 3=$ Upper Middle Income $-\$ 3,706$ to $\$ 11,455 ; 4=$ High Income - over \$11,456). \$US throughout. 'Key Indicators for Other Economies' table in World Bank, World Development Reports (especially 2009), main source for very small states. Not at PPP. 'Best guess' estimates for seven entities: Anguilla assumed '4' (CIA World Factbook, 2008 est. of GDP per capita at PPP $=\$ 12,200$; UK FCO est. at $2009=\$ 18,623)$. British Virgin Islands assumed '4' (CIA 2004 est. of GDP per capita at PPP $=\$ 38,500$; UK FCO est. $2010=$ $\$ 30,282$ ). Guadeloupe assumed '4' (Eurostat 2007 GDP per capita at PPS $=€ 17,400=$ $\$ 23,385$ ). French-Guiane assumed ' 4 ' (Eurostat 2007 GDP per capita at PPS $=€ 12,900=$ $\$ 17,337$ ). Martinique assumed '4' (Eurostat 2007 GDP per capita at PPS $=€ 19,100=$ $\$ 25,670$ ). Montserrat assumed '3' (CIA 2002 est. GDP per capita at PPP $=\$ 3,400$; UK FCO 2009 GDP per capita $=$ EC $\$ 31,725=\$$ US11,750). Turks \& Caicos Islands assumed '4' (CIA 2007 GDP per capita at PPP $\$ 11,500$ ).

AGRIC: Agriculture, forestry and fisheries percentage of GVA, 2007. UN Main Accounts Aggregates Database. National currency values. Converted to ordinal variable with six classes $(1=0-5 \%$ of GVA; $2=5-10 \% ; 3=10-15 \% ; 4=15-20 \% ; 5=20-25 \% ; 6=$ over $25 \%)$. For 31 countries, UN continuous data for 2007 converted to ordinal variables. For five entities, 'best guess' estimate ordinal class derived: Guadeloupe assumed '1' (Eurostat agriculture as \% GDP in 2007 = 2.7\%); French-Guiane assumed ' 1 ' (Eurostat $2007 \%$ GDP = 4.4\%); Martinique assumed ' 1 ' (Eurostat $2007 \%$ GDP $=2.2 \%$ ); Montserrat assumed ' 1 ' (CIA World Factbook 2011 est. \% GDP = 1.6\%); US Virgin Islands assumed '1' (CIA 2003 est. of $\%$ GDP $=1.0 \%)$.

INDUST: Industry (manufacturing, construction, mining and utilities) percentage of GVA. Source as AGRIC. Converted to the same six ordinal classes. For 31 countries, UN continuous data for 2007 converted to ordinal variables. For five entities, 'best guess' estimate ordinal class derived: Guadeloupe assumed '2' (Eurostat manufacturing as \% GDP in $2007=5.2 \%$ ); French-Guiane assumed '2' (Eurostat $2007 \%$ GDP $=10.4 \%$ ); Martinique assumed ' 2 ' (Eurostat $2007 \%$ GDP $=7.8 \%$ ); Montserrat assumed ' 5 ' (CIA World Factbook 2011 est. \% GDP $=23 \%$ ); US Virgin Islands assumed '4' (CIA 2003 est. of $\%$ GDP $=19 \%$ ).

TOURISTS: Caribbean Tourism Organisation (CTO)/UN World Tourism Organisation (UNWTO) data, 2007. Numbers of tourist arrivals per 1,000 population. 2007 population data.

CRUISE: CTO/UNWTO data, 2007. Cruise visitors per 1,000 population. 2007 population data. No UNWTO data for Guyana, French-Guiane and Turks \& Caicos Islands. Cruise tourists assumed zero for Guyana and French-Guiane. Government statistical website figure of 379,936 used for Turks \& Caicos Islands in 2007.

FINAN: Binary variable for presence/absence of offshore finance center. Rose and Spiegel (2007) list.

RESOUR: Binary variable for presence/absence of major export-earning resource. Belize (oil, timber, fish); French-Guiane (timber); Guyana (fish, timber, bauxite); Jamaica (bauxite and alumina); Suriname (alumina, gold, oil, timber, fish); Trinidad \& Tobago (oil \& gas); Cuba (oil, nickel). Excludes agricultural resources and 'green' environment resources (e.g., beaches, land area, mountains) or built environment. Comprises oil \& gas, other minerals, fish and timber resources. Variable is authors' own construction drawing on UK data, government statistical websites and publications. Rough rule of thumb of approximately $10 \%$ or more of export earnings from the resources as threshold value. 
Figure 1: Dendrogram of Cluster Analysis of 28 Caribbean States, 2007

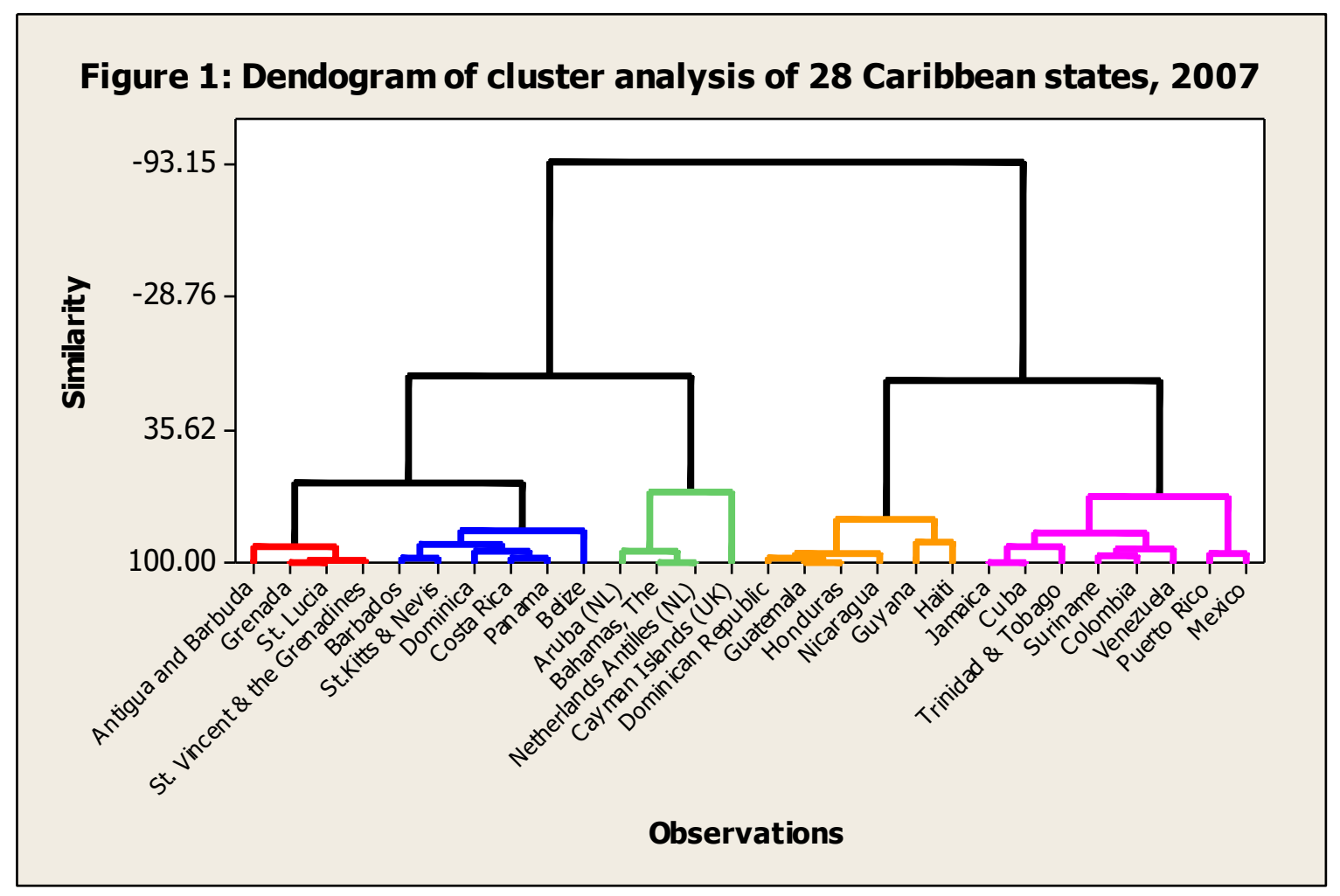

Figure 1

Index: Cluster 1: red; Cluster 2: blue; Cluster 3: purple; Cluster 4: yellow; Cluster 5: green. 
Figure 2: Dendrogram of Cluster Analysis of 36 Caribbean States, 2007

Figure 2: Dendogram of cluster analysis of 36 Caribbean states, 2007

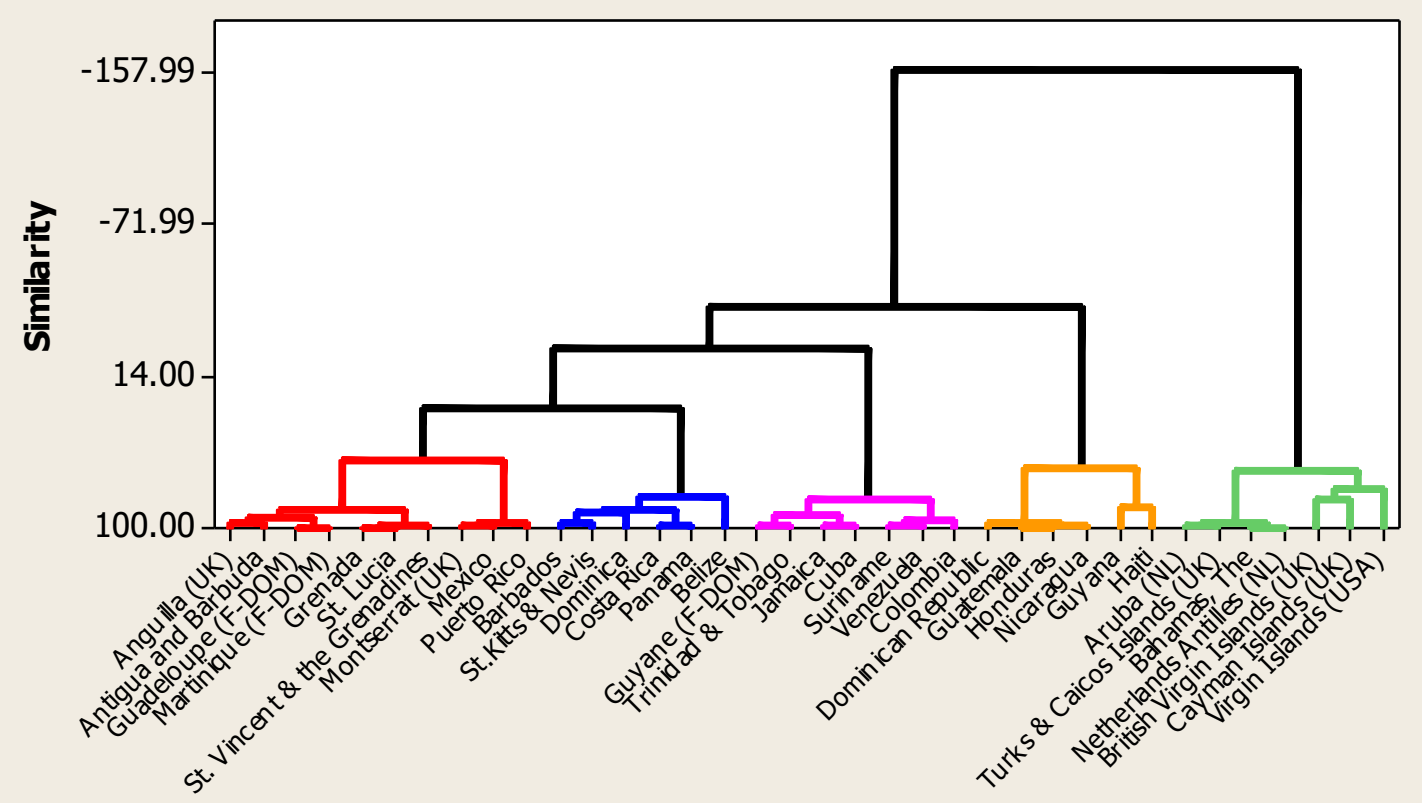

Observations

Index: Cluster 1: red; Cluster 2: blue; Cluster 3: purple; Cluster 4: yellow; Cluster 5: green. 